\title{
Economic Aspect of Growing Pigs with Respect to Sex and Immunocastration
}

\author{
Michal Šprysl, Eva Kluzáková, Jaroslav Čítek, Roman Stupka, Kateřina Zadinová \\ Department of Animal Science, Faculty of Agrobiology, Food and Natural Resources, Czech University \\ of Life Sciences Prague, Czech Republic
}

\begin{abstract}
The minimization of boar taint according to welfare appears to be immunocastration. For this purpose a test was carried out for a total of 80 piglets in the growing stage. Animals were housed by sex, respectively 20 boars, 20 immunocasatrates, 20 barrows and 20 gilts. Animals were fed ad libitum, and the production variables were observed with an emphasis on the overall economy of their production. Intergroup differences were tested by variance analyse and the test groups of growing pigs were evaluated using a profit formula.

It was shown that animals in the growing period had excellent parameters of the fattening (in the 65 days, the total gain was $19 \mathrm{~kg}$, with daily feed intake below $0.7 \mathrm{~kg}$, feed conversion ratio $1.2 \mathrm{~kg}$ and average daily gain 540-560 g). The effect of sex, or the castration of young pigs on the economy of the pig production in growing period is proved to be insignificant. This hypothesis was confirmed.
\end{abstract}

\section{Keywords}

Pig, grower period, fattening capacity test, sex, immunocastration, profit formula, economy.

Šprysl, M., Kluzáková, E., Čítek, J., Stupka, R. and Zadinová, K. (2019) "Economic Aspect of Growing Pigs with Respect to Sex and Immunocastration", AGRIS on-line Papers in Economics and Informatics, Vol. 11, No. 2, pp. 95-102. ISSN 1804-1930. DOI 10.7160/aol.2019.110209.

\section{Introduction}

Nowadays the emphasis is put on the food production. Problems of dioxins, GMOs, general protein deficit, antibiotics, use of animal proteins in animal feed, mycotoxins, BSE, etc. have been and are being solved. For pig production, this means, on the one hand, constant improvements their performance by classical zootechnical organizational tools, ie hybridization and selection (Tholen et al., 1996; Edwards, 2005; Ngapo, Gariepy, 2008; Babovic, 2011). On the other hand, an implementing a new technologies to make more efficient and improve living conditions. Technology innovations take place in all categories of pigs, some of them raise a debate on ethics and welfare. At present, within welfare of livestock, it is using the influence of different sexes on their production performance. In this case, it is a solution to the problem of eliminating castration of the boar piglets (Dekkers and Hospital, 2002; Krieter, 2002; Prunier et al., 2006; Fredriksen et al., 2011; Maiorano et al., 2012; Velechovská, 2012; etc.). Measure eliminates the occurrence of "boar taint" in pork meat and fat. This is unacceptable for consumers (Engelsma et al., 2007). Admissible levels of both are for androstenone > 1ppm, skatole $>0.25$ ppm (Xue et al., 1996; Whittington et al., 2011). The problem is still realized by surgical castration without anesthesia (Edwards 2008; Fredriksen et al., 2008; Boneau et al., 2009; Batorek et al., 2012). The above mentioned thema solve and realize in the EU the European Food Authority, the trade chains and the relevant legislation (Bernardy, 2010). This measure is tolerated by the end of 2018 .

The recommended option of eliminating boar taint at minimal economic loss is immunostaining. It is a vaccine stimulating the production of specific gonadotropin-releasing hormone (GnRH) antibodies suppressing testicular function (Zamaratskaia et al., 2004). Its application is recommended at 8 weeks of age with subsequent revaccination after 4 weeks. The thesis deals with the extent to which the sex and immunocastration of pigs influences their production performance in the growing period, respectively their impact on the production economy.

The objective of the test in the growing period fattening (GP), (7-30 kg), was to verify 
the influence of sex, respectively the method of castration (boars- $\hat{\sigma}$, immunocastrates-ik, barrows- $\hat{\hat{\alpha}}$, gilts- + ) on its parameters of fattening capacity with emphasis to the overall economy of their production.

\section{Materials and methods}

\section{Hypothesis}

The first vaccine of boar has no significant effect on the production level performance and effectiveness compared to other sex categories in pigs.

\section{Animals}

The research test was conducted in March-April 2017. A total of 80 pigs crossbred population D x (LWxL) were housed in the Experimental Test Station of the Czech University of Life Sciences Prague and divided according to sex. There were 20 boars (ఏ), 20 immunocastrates (ik), 20 barrows (气̂) and 20 gilts (ㅇ). All animals were labeled by electronic ear chips. The growing period of animals lasted 36 days (from weaning to 66 days of age) of their age with a live weight of $9-30 \mathrm{~kg}$.

\section{Housing, microclimate}

In the growing period, the animals were housed in groups of 20 by sex $(\hat{\partial}, \mathrm{ik}, \hat{\Omega},+$ ) $)$. Microclimate in the test station, respectively temperature, gas concentration, relative humidity, were controlled automatically and monitored every hour to meet the requirements of the animals of the given age (MÖLLER, s.r.o., AGE s.r.o.).

\section{Castration}

In order to obtain the immunocastrates, the $2^{\text {nd }}$ group of boars was chemical castrated the $5^{\text {th }}$ day after penned. This group of animals received Improvac $\AA$, which contained $200 \mu \mathrm{g}$ of $\mathrm{GnRH}$ protein conjugate $/ \mathrm{ml}$ in an aqueous adjuvant solution.

\section{Nutrition, feeding}

They were fed ad libitum with complete feed mixtures (CFM) the composition of which were continually adjusted with respect to the age and weight of the pigs. In the growing period, the CFM-starter (creap and weaning by De Hoist, The Netherlands), ČOS and $\mathrm{A}_{1}$ were used (Table 1, Table 2).

\section{Variables}

The purpose was to obtain a longitudinal size-age type dataset, where all the animals have all the data from the same age in the test. Due to the technological equipment of the test station, the data characterizing the growing stage in pigs were obtained as an average.

For data describing the growth of the monitored animals, at each stage of each animal we regularly weighed at the same time at weekly intervals, at the same time, to obtain a live weight in $\mathrm{kg}$ (LW). In addition, the animal's daily feed intake in $\mathrm{kg}$ (DFI), feed conversion in $\mathrm{kg}$ (FCR) and average daily gain in $\mathrm{g}$ (ADG) were monitored as well.

\begin{tabular}{|l|c|c|}
\hline CFM & Feeding time (day) & Price of 1 kg CFM (CZK/EUR) \\
\hline Creap & $31-38$ & $17.85 / 0.66$ \\
\hline Weaning & $38-45$ & $14.95 / 0.55$ \\
\hline ČOS & $45-59$ & $9.85 / 0.37$ \\
\hline A1 & $59-66$ & $7.09 / 0.26$ \\
\hline
\end{tabular}

Note: CFM prices and food components relate to January-March 2017 Source: Pig Breeding Test Station CULS Prague

Table 1: Feeding scheme for pigs in the growing period.

\begin{tabular}{|c|c|c|c|c|c|c|c|}
\hline ČOS & $\%$ & $\mathrm{CZK} / \mathrm{kg}(\mathrm{EUR} / \mathrm{kg})$ & CZK/EUR & A1 & $\%$ & $\mathrm{CZK} / \mathrm{kg}(\mathrm{EUR} / \mathrm{kg})$ & CZK/EUR \\
\hline wheat & 40 & $5.5(0.20)$ & $2.2 / 0.08$ & wheat & 44 & $5.5(0.20)$ & $2.42 / 0.09$ \\
\hline barely & 29 & $5(0.19)$ & $1.45 / 0.05$ & barely & 35.3 & $5(0.19)$ & $1.76 / 0.07$ \\
\hline soya & 20 & $11.5(0.43)$ & $2.3 / 0.09$ & soya & 17.7 & $36(1.33)$ & $2.04 / 0.08$ \\
\hline sugi & 10 & $36(1.33)$ & $3.6 / 0.13$ & sugi & & $36(1.33)$ & \\
\hline oil & 1 & $30(1.11)$ & $0.3 / 0.01$ & oil & . & $30(1.11)$ & \\
\hline aminogold & . & $29(1.07)$ & . & aminogold & 3 & $29(1.07)$ & $0.87 / 0.03$ \\
\hline Total & \multicolumn{3}{|c|}{$9.85(0.37)$} & Total & \multicolumn{3}{|c|}{$7.09(0.26)$} \\
\hline
\end{tabular}

Note: CFM prices and food components relate to January-March 2017

Source: Pig Breeding Test Station CULS Prague

Table 2: Composition and price of used CFM. 


\section{Processing results}

All partial data were processed by common mathematical and statistical methods (SAS Inst. Inc., Cary, NC), expressed with respect to sex in tables. Differences between groups were tested by variance analysis (Tuky test).

When determining the yields of subpopulations in pigs, it is necessary to assess their performance fundamentally complex (Sellier, 1976). It is the expression of the profitability of the test groups using the profit formula, which is determined by the profit equation used in the production economy and the econometrics in finding the variable cost corresponding to the maximum profit that can be achieved.

The test was therefore evaluated economically with regard to test groups of pigs using a profitable function (Poděbradský, 1980; Župka, 1992) of the following shape:

$Z c=\left\{c_{1} y_{1}-\left[n_{1} x_{1}+n_{2} x_{2}+\left(n_{3}: x_{3}\right)+A\right]\right\} x r$,

where

$r=365:\left(x_{2}+k\right) ; x_{2}=\left(y_{1}-y_{0}\right): x_{2} ; Z c=Z x r$,

where:

$Z c$ - profit per capita unit per year,

$Z$ - profit per slaughter pig,

$r$ - the rate of pig turnover per year,

$\mathrm{c}_{1}$ - the average realization price per unit of half-carcasses production,

$n_{1}$ - cost (price) per CFM unit,

$n_{2}$ - fixed costs for 1 feeding day of fattening pig,

$n_{3}$ - costs per 1 sow and litter without the costs of nursing and feeding of piglets,

$A$ - costs of nursing and feeding of piglets,

$y_{1}$ - carcasses weight, $\dot{y}_{1}$ - live weight of slaughter pig,

$y_{0}$ - live weight of grower when start of fattening,

$x_{1}$ - amount of CFM consumed,

$x_{2}$ - fattening time,

$x_{2}$ - average daily weight gain from start of growing to removal,

$x_{3}$ - number of reared piglets per sow and litter,

$k$ - days between 2 turns.

In our case, this is reduced only to indicators that measure the running test costs, ie the cost of purchasing weaners and feed costs.

\section{Results and discussion}

Evaluation of the fattening capacity of tested pigs by sex in the growing period is showed in Tables 3-4.

At the beginning of the growing period (at 31 days), the highest average starting weight had boars $(9.4 \mathrm{~kg})$ and barrows $(9.1 \mathrm{~kg})$. Followed by immunocastrates $(9 \mathrm{~kg})$ and the lightest live weight were in gilts $(8.9 \mathrm{~kg})$. Because the differences in weights were insignificant, other phenotypic values of production performance can be compared to each other.

In the following weeks, the order of precedence was alternated, so at the end of the test, the order f convenience was boars $(29.1 \mathrm{~kg})$, immunocastrates $(28.4 \mathrm{~kg})$, gilts $(28.3 \mathrm{~kg})$ and barrows $(28 \mathrm{~kg})$. Concerned of the total gain per grower period $(\Sigma)$, the order of convenience was $19.7 \mathrm{~kg}$ for boars, for gilts and immunocastrates $19.4 \mathrm{~kg}$ and barrows $19 \mathrm{~kg}$.

In the daily feed intake (DFI) at the beginning (31 days of age) was the order barrows and boars $(0.3 \mathrm{~kg} /$ day $)$, then gilts with immunocastrates

\begin{tabular}{|c|c|c|c|c|c|c|c|c|c|c|c|c|}
\hline \multirow{3}{*}{$\begin{array}{l}\text { Variable } \\
\text { Age } \\
\text { (days) }\end{array}$} & \multicolumn{8}{|c|}{ LW (kg) } & \multicolumn{4}{|c|}{ DFI (kg/day) } \\
\hline & \multicolumn{2}{|c|}{$\hat{\Omega}$} & \multicolumn{2}{|c|}{ q } & \multicolumn{2}{|c|}{$\hat{\sigma}$} & \multicolumn{2}{|c|}{ ik } & \multirow{2}{*}{$\frac{\hat{\delta}}{x}$} & \multirow{2}{*}{$\frac{q}{\mathrm{x}}$} & \multirow{2}{*}{$\frac{\delta}{x}$} & \multirow{2}{*}{$\frac{\mathrm{ik}}{\mathrm{x}}$} \\
\hline & $\mathrm{x}$ & $\mathrm{s}$ & $\mathrm{x}$ & $\mathrm{s}$ & $\mathrm{x}$ & $\mathrm{S}$ & $\mathrm{x}$ & $\mathrm{s}$ & & & & \\
\hline 31 & 9.1 & 1.4 & 8.9 & 0.4 & 9.4 & 1.8 & 9.0 & 0.4 & 0.3 & 0.2 & 0.3 & 0.2 \\
\hline 38 & 11.0 & 1.8 & 9.9 & 3.0 & 10.8 & 1.5 & 11.2 & 3.0 & 0.4 & 0.3 & 0.3 & 0.3 \\
\hline 45 & 12.8 & 2.4 & 13.8 & 1.0 & 13.7 & 2.6 & 16.2 & 1.0 & 0.6 & 0.6 & 0.6 & 0.6 \\
\hline 52 & 18.1 & 4.7 & 18.1 & 1.7 & 18.8 & 2.7 & 18.4 & 3.5 & 0.9 & 0.8 & 0.8 & 0.6 \\
\hline 59 & 21.8 & 6.4 & 23.5 & 2.8 & 23.3 & 3.3 & 23.5 & 2.8 & 0.9 & 1.1 & 1.0 & 1.1 \\
\hline 66 & 28.0 & 7.5 & 28.3 & 3.0 & 29.1 & 3.3 & 28.3 & 3.0 & 1.3 & 1.2 & 1.3 & 1.3 \\
\hline$\Sigma$ & 19.0 & 7.1 & 19.4 & 2.9 & 19.7 & 2.5 & 19.4 & 2.9 & 0.69 & 0.69 & 0.68 & 0.66 \\
\hline
\end{tabular}

Note: Significance: all intergroup differences were statistically insignificant Source: Pig Breeding Test Station CULS Prague 


\begin{tabular}{|c|c|c|c|c|c|c|c|c|c|c|c|c|}
\hline Variable & \multicolumn{4}{|c|}{ FCR (kg CFM/kg gain) } & \multicolumn{8}{|c|}{ ADG $(g)$} \\
\hline \multirow{2}{*}{$\begin{array}{l}\text { Age } \\
\text { (days) }\end{array}$} & $\hat{\theta}$ & 우 & $\hat{0}$ & ik & \multicolumn{2}{|c|}{$\underline{\Omega}$} & \multicolumn{2}{|c|}{ 우 } & \multicolumn{2}{|c|}{ 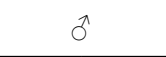 } & \multicolumn{2}{|c|}{$\mathrm{ik}$} \\
\hline & $x$ & $\mathrm{x}$ & $x$ & $x$ & $\mathrm{x}$ & $\mathrm{s}$ & $\mathrm{x}$ & $\mathrm{s}$ & $\mathrm{x}$ & $\mathrm{s}$ & $\mathrm{x}$ & $\mathrm{s}$ \\
\hline 38 & 1.4 & 2.34 & 1.6 & 1.0 & 273 & 94 & 139 & 449 & 207 & 160 & 317 & 148 \\
\hline 45 & 2.2 & 1.01 & 1.4 & 0.8 & 266 & 240 & 555 & 461 & 417 & 271 & 705 & 187 \\
\hline 52 & 1.2 & 1.36 & 1.1 & 1.9 & 744 & 543 & 613 & 143 & 721 & 165 & 319 & 228 \\
\hline 59 & 1.7 & 1.44 & 1.5 & 1.7 & 540 & 296 & 773 & 184 & 653 & 147 & 640 & 196 \\
\hline 66 & 1.4 & 1.81 & 1.5 & 1.7 & 884 & 232 & 688 & 127 & 817 & 142 & 784 & 119 \\
\hline$\Sigma$ & 1.28 & 1.25 & 1.21 & 1.20 & 541 & 202 & 554 & 83 & 563 & 70 & 553 & 136 \\
\hline
\end{tabular}

Source: Pig Breeding Test Station CULS Prague

Table 4: Fattening capacity evaluation with respect to sex of the growing period in pigs $(n=79)$.

$(0.2 \mathrm{~kg})$. Over the next weeks the DFI of all groups were practically the same. At the end of the growing period, the lowest daily feed intake was in gilts $(1.2 \mathrm{~kg})$, the other categories showed this variable $1.3 \mathrm{~kg}$. The order of total daily feed intake is barrows and gilts $(0.69 \mathrm{~kg})$, boars $(0.68 \mathrm{~kg})$ and immunocastrates $(0.66 \mathrm{~kg})$.

As the feed conversion ratio (FCR) is concerned, at the beginning growing period (38 days), the order of convenience was immunocastrates (1 kg), barrows (1.4 kg), boars $(1.6 \mathrm{~kg})$, gilts $(2.34 \mathrm{~kg})$, however in the next following weeks the order was changed. In terms of economic advantage, the overall average feed conversion ratio for barrows was the worst $(1.28 \mathrm{~kg})$, following gilts $(1.25 \mathrm{~kg})$, immunocastrates $(1.21 \mathrm{~kg})$ and boars $(1.20 \mathrm{~kg})$.

When it comes to the growth intensity of the test groups of animals in the test, at the beginning test the highest ADG shows immunocastrates (317 g), barrows (273 g), boars (207 g) and gilts (139 g). At the end of the growing period the order of advantage was barrows (884 g), boars $817 \mathrm{~g}$ ), immunocastrates $(784 \mathrm{~g})$ and gilts $(688 \mathrm{~g})$. Regarding the overall order of average growth intensity, the order of the groups were boars (563 g), gilts $(554 \mathrm{~g})$, immunocastrates $(553 \mathrm{~g})$ and barrows (541 g). However the differences between groups were statistically insignificant.

The following Table 5 evaluates the indicators influencing the economy of pigs in the growing period.

It is clear from the table that the initial body weight of all groups were balanced, they moved in a range of $0.5 \mathrm{~kg}$. This fact is most important for tests, because the body weight/age, significantly affecting other performance indicators. Gilts at 31 days reached the lowest average weight, $8.9 \mathrm{~kg}$. The heaviest were the boars $(9.4 \mathrm{~kg})$ who also reached the highest absolute body gain $(19.7 \mathrm{~kg})$ at the end of the growing period. The same values (19.4 $\mathrm{kg})$ achieved immunocastraces and gilts, barrows then $19 \mathrm{~kg}$. The initial body weight then affected the price of piglets, ranging from 1 162/43.01 (gilts) to $1216 / 45.00 \mathrm{CZK} / \mathrm{EUR}$ (boars).

As it was mentioned above, the economic evaluation of the test included only the costs of buying weaner and feed. The facts are documented in Tables 6 and 7.

It is clear that the DFI of the experimental animals in the test without respect to sex was virtually the same $(28-29 \mathrm{~kg})$, which was reflected at practically the same feed cost (242-264/8.96 - 9.77 CZK/EUR) and the average price of $1 \mathrm{~kg}$ CFM (8.70 - 9,08/0.32 - 0.34 CZK/EUR).

The lowest cost per 1 piglet, due to low weight, are in gilts (1 162/43.01 CZK/EUR), the highest, due to the highest weight, is for boar $(1216 / 45.00 \mathrm{CZK} /$ EUR). The purchase price of the immunocastrate was $1170 / 43.30 \quad \mathrm{CZK} / \mathrm{EUR}$ and the barrow CZK /EUR 1 179/43.63. Adding the cost of a feed then costs per 1 piglet ranging from 1 418/52.48 CZK/EUR (gilts) to $1472 / 54.48 \mathrm{CZK} / \mathrm{EUR}$ (boars).

By dividing them by the weight of a given group at the end of the test, the cost per $1 \mathrm{~kg}$ of the test can be determined. However, the differences between groups are small, at an absolute value of $1.85 / 0.07 \mathrm{CZK} / \mathrm{EUR}$. It can be said that the most expensive kilogram of the animal was for the barrow (51.57/1.91 CZK/EUR), the cheapest for the immunocastrate (49.72/1.84 CZK/EUR). Price of $1 \mathrm{~kg}$ of boar, resp. gilt, then 50.58/1.87, respectively 50.11/1.86 CZK/EUR.

As far as the test results are concerned, Hovorka et al. (1983) has already pointed out that the sex or castration, and hence the economy of production, significantly affects production characters in pigs. But this influence starts be 


\begin{tabular}{|l|c|c|c|c|}
\hline Variable / sex & $\hat{\Omega}$ & $q$ & $\hat{1}$ & $\mathrm{Ik}$ \\
\hline Average live weight $(\mathrm{LW})$ at 31 days $(\mathrm{kg})$ & 9.1 & 8.9 & 9.4 & 9.0 \\
\hline Piglet price $(130 \mathrm{CZK} / \mathrm{kg}) /(4.81 \mathrm{EUR} / \mathrm{kg})$ & $1179 / 43.63$ & $1162 / 43.01$ & $1216 / 45.00$ & $1170 / 43.03$ \\
\hline Average live weight $(\mathrm{LW})$ at 66 days $(\mathrm{kg})$ & 28.0 & 28.3 & 29.1 & 28.4 \\
\hline Total body gain $(\mathrm{kg})$ & 19.0 & 19.4 & 19.7 & 19.4 \\
\hline
\end{tabular}

CFM prices and food components relate to January-March 2017

Source: Pig Breeding Test Station CULS Prague

Table 5: Cost per 1 weaner in the growing period with respect to sex.

\begin{tabular}{|c|c|c|c|c|c|c|c|c|c|}
\hline \multirow[t]{2}{*}{ Component } & \multirow{2}{*}{$\begin{array}{l}\text { Price / kg } \\
\text { CZK / EUR }\end{array}$} & \multicolumn{2}{|r|}{$\hat{0}$} & \multicolumn{2}{|r|}{ 우 } & \multicolumn{2}{|r|}{$\sigma^{\pi}$} & \multicolumn{2}{|r|}{ ik } \\
\hline & & $\mathrm{kg}$ & $\mathrm{CZK} / \mathrm{EUR}$ & $\mathrm{kg}$ & CZK/EUR & $\mathrm{kg}$ & CZK/EUR & $\mathrm{kg}$ & CZK/EUR \\
\hline Creep & $17.85 / 0.66$ & 0.8 & $14 / 0.52$ & 0.6 & $10 / 0.37$ & 0.8 & $14 / 0.52$ & 0.5 & $9 / 0.33$ \\
\hline Weaning & $15.0 / 0.56$ & 2.7 & $40 / 1.48$ & 2.3 & $34 / 1.26$ & 2.3 & $34 / 1.26$ & 2.1 & $32 / 1.18$ \\
\hline ČOS & $9.9 / 0.37$ & 10.2 & $101 / 3.74$ & 9.8 & $96 / 3.55$ & 9.9 & $97 / 3.59$ & 8.2 & $81 / 3.00$ \\
\hline A1 & $7.1 / 0.26$ & 15.4 & $109 / 4.03$ & 16.5 & $117 / 4.33$ & 15.7 & $112 / 4.15$ & 16.9 & $120 / 4.44$ \\
\hline Total (kg) & . & 29 & $264 / 9.77$ & 29 & $257 / 9.51$ & 29 & $257 / 9.51$ & 28 & $242 / 8.96$ \\
\hline $\begin{array}{l}\text { Price } \\
(\mathrm{CZK} / \mathrm{kg})(\mathrm{EUR} / \mathrm{kg})\end{array}$ & & \multicolumn{2}{|c|}{$9.08(0.34)$} & \multicolumn{2}{|c|}{$8.84(0.33)$} & \multicolumn{2}{|c|}{$8.95(0.33)$} & \multicolumn{2}{|c|}{$8.70(0.32)$} \\
\hline
\end{tabular}

CFM prices and food components relate to January-March 2017

Source: Pig Breeding Test Station CULS Prague

Table 6: Consumption and price of TFMs in test with respect to sex.

\begin{tabular}{|c|c|c|c|c|}
\hline Variable / sex & $\hat{0}$ & q & $\hat{0}$ & $\mathrm{ik}$ \\
\hline \multicolumn{5}{|l|}{ Cost per: } \\
\hline - 1 weaner CZK (EUR) & $\begin{array}{c}1179 \\
(43.63)\end{array}$ & $\begin{array}{c}1162 \\
(43.01)\end{array}$ & $\begin{array}{c}1216 \\
(45.00)\end{array}$ & $\begin{array}{c}1170 \\
(43.30)\end{array}$ \\
\hline - feeding one weaner in test CZK (EUR) & $\begin{array}{c}264 \\
(9.77)\end{array}$ & $\begin{array}{c}257 \\
(9.51)\end{array}$ & $\begin{array}{c}257 \\
(9.51)\end{array}$ & $\begin{array}{c}242 \\
(8.96)\end{array}$ \\
\hline Cost per 1 weaner (CZK (EUR) / head) & $\begin{array}{c}1444 \\
(42.34)\end{array}$ & $\begin{array}{c}1418 \\
(52.48)\end{array}$ & $\begin{array}{c}1472 \\
(54.48)\end{array}$ & $\begin{array}{c}1412 \\
(52.26)\end{array}$ \\
\hline Cost per 1 weaner (CZK(EUR) / kg) & $\begin{array}{l}51.57 \\
(1.91)\end{array}$ & $\begin{array}{l}50.11 \\
(1.86)\end{array}$ & $\begin{array}{l}50.58 \\
(1.87)\end{array}$ & $\begin{array}{l}49.72 \\
(1.84)\end{array}$ \\
\hline
\end{tabular}

CFM prices and food components relate to January-March 2017

Source: Pig Breeding Test Station CULS Prague

Table 7: Economic evaluation of test groups of pigs on the basis of purchase price of pigs and CFMs by sex.

significant approximately from the body weight of $50-70 \mathrm{~kg}$ in pigs (Stupka et al., 1998; Vanheukelom et al., 2012; Robina et al., 2013; Serano et al., 2013). With respect of the genetic shift in the pig population, as well as the economics, Morales et al. (2011), Grela et al. (2013), Čítek et al. (2014), Šprysl and Stupka (2003) also confirm this.

\section{Conclusion}

The animals in the test during the growing period showed excellent fattening parameters, with a total increase of $19 \mathrm{~kg}$ in 65 days, a DFI of $0.7 \mathrm{~kg}$, a FCR $1.2 \mathrm{~kg}$ and an ADG of 540-560 g.

The high performance of current modern pig genotypes, especially in the growing periode later influencing the overall production economy, was pointed out by Stupka et al. (1998). They mentioned that due to "maker assisted selection (MAS)" can be expected a significant changes in reproductive and production performance in pigs. This phenomenon also needs to be adapted to new technologies. The authors also demonstrated that the influence of sex and castration in young pigs is insignificant as mentioned already Hovorka et al., (1983). Genetic progress in production performance in the pig population, and the impact of sex on the economy also showed above mentioned authors (Šprysl and Stupka, 2003; Morales et al. 2011; Grela et al. 2013; Čítek et al. 2014).

In assessing the overall economy showed that the ascending order of preference, in terms of economic benefit, in this test achieved 
immunocastrates, gilts, barrows and boars. It was confirmed, that the influence of sex or castration in young pigs is insignificant. This fact confirmed the given hypothesis.

It can be said that "classical" pathways, minimizing boar taint in pork meat (castration, immunocastration), with regard to the pig production economy and "no harm to the animals", will be pursued in the future in other ways by breeding (Wood et al.) and successive changes in consumer habits (Lamb, 1994).

\section{Acknowledgements}

This study was supported by the Ministry of Education, Youth and Sports of the Czech Republic (Project "S" No. MSM 6046070901 and INTER-COST: LTC17), and by and the National Agency for Agricultural Research of the Czech Republic (Grant QJ1510191).

Corresponding authors

doc. Ing. Michal Šprysl, CSc.,

Department of Animal Science, Faculty of Agrobiology, Food and Natural Resources

Czech University of Life Sciences Prague, Kamýcká 129, 16500 Prague - Suchdol, Czech Republic

Email:sprysl@af.czu.cz

Ing. Eva Kluzáková, Ph.D.

Department of Animal Science, Faculty of Agrobiology, Food and Natural Resources Czech University of Life Sciences Prague, Kamýcká 129, 16500 Prague - Suchdol, Czech Republic

Email: kluzakova@af.czu.cz

\section{References}

[1] Andresen, O. (1975) "5alpha-androstenone in peripheral plasma of pigs, diurnal variation in boars, effects of intravenous HCG administration and castration“, Acta Endocrinol (Copenhagen), Vol. 78, No. 2, pp. 385-391. ISSN 0001-5598.

[2] Babovic, J., Caric, M., Djordjevic, D. and Layic, S. (2011) "Factors influencing the economics of the pork meat production“, Agricultural Ecocnomics (Zemédělská Ekonomika), Vol. 57, No. 4, pp. 203-209. ISSN 0139-570X.

[3] Batorek, N., Candek-Potokar, M., Bonneau, M. and Van Milgen, J. (2012) „Metaanalysis of the effect of immunocastration on the production performance, reproductive organs, and boar taint compounds in pigs“", Anima, Vol. 6, No. 8, pp. 1330-1338. E-ISSN 1751-732X, ISSN 1751-7311. DOI 10.1017/S1751731112000146.

[4] Bonneau, M., Oliver, M. A., Fredriksen, B., Von Borell, E., Lundström, K. and De Roest, K. (2009) "Report on recommendations for research and policy support", D 4.1 of the EU-supported project PIGCAS. [Online]. Available: http://w3.rennes.inra.fr/pigcas [Accessed: 10 Dec. 2018].

[5] Bernardy, J. (2010) "Kastrace prasat jako evropské dilema”, Veterinářství, Vol. 60, pp. 372 - 374. ISSN 0506-8231. (in Czech).

[6] Čítek, J., Stupka, R., Šprysl, M., Vehovský, K., Okrouhlá, M., Brzobohatý, L. (2014) "Ekonomika výroby vepřového masa u kanečků a imunokastrátů”, Náš chov, Vol. 74, No. 11, pp. 25 - 27. ISSN 0027-8068. (in Czech).

[7] Dekkers, J. C. M. and Hospital, F. (2002) "The use of molecular genetics in the improvement of agricultural populations“", Natural Reviews Genetics, Vol. 3, No. 1, pp. 22-32. ISSN 1471-0056.

[8] Edwards, S. A. (2005) "Product quality attributes associated with outdoor pig production“, Livestock Production Science, Vol. 94, pp. 5-14. ISSN 0301-6226. DOI 10.1016/j.livprodsci.2004.11.028.

[9] Edwards, S. A., Von Borell, E., Fredriksen, B., Lundström, K., Oliver, M. A. and De Roest, K. (2008) "A synthesis of current knowledge on surgical castration of pigs and its alternatives", In $59^{\text {th }}$ Annual meeting of the EAAP, Vilnius, August 24-27, Session 14. 
[10] Engelsma, K. A., R., Bergsma, R., Harlizius, B., Ducro-Steverink, D. and Knol, E. (2007) "Genetic parameters for components of boar taint and their relation with carcass quality and female fertility", EAAP 58 Annual Meeting of the EAAP, Dublin, Ireland, August 26-29, Session 10, poster 27, pp. $1-8$.

[11] Fredriksen, B., Font I Furnols, M., Lundström, K., Prunier, A., Tuyttens, F. and Migdal, W. (2008) "Practice on castration of piglets in Europe", In $59^{\text {th }}$ Annual meeting of the EAAP, Vilnius, Lithuania, August 24-27, 93 p.

[12] Fredriksen, B., Johnsen, A. M. S. and Skuterud, E. (2011) "Consumer attitudes towards castration of piglets and alternatives to surgical castration”, Research in Veterinary Sciences, Vol. 90, No. 2, pp. 352 - 357. ISSN 0034-5288. DOI 10.1016/j.rvsc.2010.06.018.

[13] Grela, E. R., Kowalczuk-Vasilev, E. and Klebaniuk, R. (2013) "Performance, pork quality and fatty acid composition of entire males, surgically castrated or immunocastrated males, and female pigs reared under organic system", Polish Journal of Veterinary Sciences, Vol. 16, No. 1, pp. 107-114. ISSN 1505-1773. DOI 10.2478/pjvs-2013-0015.

[14] Hovorka, F. (1983) “Biologické aspekty užitkovosti prasat”, Czech University of Agriculture, Prague, 148 pp. (in Czech).

[15] Krieter, J. (2002) "Evaluation of different pig production systems including economic, welfare and environmental aspects“, Archiv für Tierzucht-Archives of Animal Breeding, Vol. 45, No. 3, pp. 223-235. ISSN 0003-9438. DOI 10.5194/aab-45-223-2002.

[16] Lamb, C. (1994) "The public perception og pig products and market developments“, In: Cole, D. J. A., Wiseman, J., Varley, M. A. Principles of Pig Science, Nottingham, pp. 385-398. ISBN 1-897676-22-0.

[17] Maiorano, G., Kapelanski, W., Bocian, M., Pizzuto, R. and Kapelanska, J. (2013) "Influence of rearing system, diet and gender on performance, carcass traits and meat quality of Polish Landrace pigs“, Animal, Vol. 7, No. 2, pp. 341-347. ISSN 1751-7311. DOI 10.1017/S1751731112001516.

[18] Morales, J. I., Cámara, L., Berrocoso, D. J., López, J. P., Mateos, G. G. and Serrano, M. P. (2011) "Influence of sex and castration on growth performance and carcass quality of crossbred pigs from 2 Large White sire lines", Journal of Animal Science, Vol. 89, pp. 3481 - 3489. ISSN 0021-8812. DOI 10.2527/jas.2010-3357.

[19] Ngapo, T. M. and Gariepy, C. (2008) "Factors affecting the eating quality of pork“, Critical Reviews in Food Science and Nutrition, Vol. 48, pp. 599-633. ISSN 1040-8398. DOI 10.1080/10408390701558126.

[20] Poděbradský, Z. (1980) "Ekonomické aspekty racionalizačních opatření v chovu prasat", Study report- Agricultural Economics, $1^{\text {st }}$ ed., ÚVTIZ, 80 p.

[21] Prunier, A., Bonneau, M., Borel, E. H., Cinotti, S., Gunn, M., Fredriksen, B., Giersing, M., Morton, D. B., Tuyttens, F. A. M. and Velarde, A. (2006) "A review of the welfare consequences of surgical castration in piglets and the evaluation of non-surgical methods", Animal Welfare, Vol. 15, pp. 277 - 289. ISSN 0962-7286.

[22] Robina, A., Viguera, J., Perez-Palacios, T., Mayoral, A. I., Vivo, J. M., Guillen, M. T. and Ruiz, J. (2013) "Carcass and meat quality traits of Iberian pigs as affected by sex and crossbreeding with different Duroc genetic lines“, Spanish Journal of Agricultural Research, Vol. 11, No. 4, pp. 1057 - 1067. ISSN 1695-971-X. DOI 10.5424/sjar/2013114-4637.

[23] Sellier, P. (1976) “The basis of crossbreeding in pigs", Livestock Production Science, Vol. 3, No. 3, pp. 203 - 226. ISSN 0301-6226. DOI 10.1016/0301-6226(76)90016-6.

[24] Serrano, M. P., Camara, L., Morales, J. I., Berrocoso, J. D., Lopez Bote, C. J. and Mateos, G. G. (2013) "Effect of gender, housing density and the interaction on growth performance and carcass and meat quality of pigs slaughtered at $110 \mathrm{~kg}$ body weight", Spanish Journal of Agricultural Research, Vol. 11, No, 1, pp. 89 - 99. ISSN 1695-971-X. DOI 10.5424/sjar/2013111-2869. 
[25] Stupka, R., Šprysl, M. and Pour, M. (1998) "The influence of live weight of pigs at the initiation of fattening on the intensity of growth and the level of weight gain with respect to sex", Sciencia Agriculturae Bohemoslovaca, Vol. 29, No. 1, pp. 39 - 50. E-ISSN ISSN 1805-9430, ISSN 1850-9430.

[26] Šimeček, K., Zeman, L. and Heger, J. (2000) "Potřeba živin a tabulky výživné hodnoty krmiv pro prasata", Czech Academy of Agricultural Sciences, Pohořelice, 78 p. (in Czech).

[27] Šprysl, M. and Stupka, R. (2003) "The effect of feeding technologies on economy of fattening pigs", Agricultural Economics - Czech, Vol. 49, No. 6, pp. 284-289. E-ISSN 1805-9295, ISSN 0139-570X. DOI 10.17221/5388-AGRICECON.

[28] Tholen, E., Bunter, K, L., Hermesch, S. and Graser, H. U. (1996) "The genetic foundation of fitness and reproduction traits in Australian pig populations, 2. Relationships between weaning to conception interval, farrowing interval, stability, and other common reproduction and production traits“, Australian Journal of Agricultural Research, Vol. 47, No. 8, pp. 1231-1274. ISSN 0004-9409. DOI 10.1071/AR9961275.

[29] Vanheukelom,V., Thielen, J. V. and Driessen, B. (2012) "Behavior, production results and meat quality of intact boars and gilts housed in unmixed groups: A comparative study", Applied Animal Behaviour Science, Vol. 142, No. 3 - 4, pp. 154 - 159. ISSN 0168-1591. DOI 10.1016/j.applanim.2012.10.004.

[30] Velechovská, J. (2012) “Imunokastrace u prasat”, Farmář, Vol. 18, No. 3, pp. 46-47. ISSN 1210-8789.

[31] Whittington, F. M., Zammerini, D., Nute, G. R., Baker, A., Hughes, S. I. and Wood, J. D. (2011) "Comparison of heating methods and the use of different tissues for sensory assessment of abnormal odours (boar taint) in pig meat", Meat Science, Vol. 88, pp. 249-255. ISSN 0309-1740. DOI 10.1016/j.meatsci.2010.12.029.

[32] Wood, J. D., Wiseman, J. and Cole, D. J. A. (1994) "Control and manipulation of meat quality“, In Cole, D. J. A., Wiseman, J. and Varley, M. A. Principles of Pig Science, Nottingham, pp. 433-455, ISBN 1-897676-22-0.

[33] Xue, J. L., Dial, G. D. and Morrison, R. B. (1996) "Comparison of the accuracies of chemical and sensory tests for detecting taint in pork", Livestock Production Science, Vol. 46, No. 3, pp. 203-211. ISSN 0301-6226. DOI 10.1016/S0301-6226(96)01385-1.

[34] Zamaratskaia, G., Babol, J., Andersson, H. and Lundstrom, K. (2004) "Plasma skatole and androstenone levels in entire male pigs and relationship between boar taint compounds, sex steroids and thyroxine at various ages", Livestock Production Science, Vol. 87, No. 2-3, pp. 91 - 98. ISSN 1871-1413. DOI 10.1016/j.livprodsci.2003.09.022.

[35] Župka, Z. (1992) “Zisková funkce”, Naučný slovník zemědělský, ZN Brázda, Prague, pp. 387 - 388. ISBN 80-209-0239-2. (in Czech). 